\title{
Economies of Childness in Cynthia Voigt's Homecoming
}

\author{
Sarah Hardstaff ${ }^{1}$ \\ Published online: 5 February 2019 \\ (c) The Author(s) 2018
}

\begin{abstract}
This paper focuses on the ways in which multiple constructions of childhood are produced, consumed and exchanged as child characters negotiate the adult world in Homecoming (1981), the first of Cynthia Voigt's Tillerman novels. Drawing on Peter Hollindale's ideas about interactions and exchanges between children and adults, the paper explores the ways in which the agency of Voigt's child characters is limited and conditioned by adult ideas about them. Yet at the same time, the children are often depicted as being able to turn these ideas to their advantage. In Homecoming's symbolic and material economies, questions about trust, risk and value come to the fore, painting a picture of precarious youth that both reflects and expands existing debates on childhood outside the text. The paper is framed in terms of entrepreneurialism, the criminality ascribed to unaccompanied children, questions of autonomy and capacity and, finally, constructions of gender.
\end{abstract}

Keywords Economic criticism · Agency · Child labour · Child entrepreneurs · Unaccompanied children

\section{Introduction}

In Signs of Childness in Children's Books, Peter Hollindale argues that "the only secure grounds for definition [of children's literature] are those that rest in the exchange between adult author and child reader of complex constructions of childhood" (1997, p. 23). Taking the central metaphor of exchange as a starting point, I

Sarah Hardstaff is a PhD candidate at the Centre for Research in Children's Literature, University of Cambridge under the supervision of Maria Nikolajeva. Her research focuses on the novels of Mildred Taylor and Cynthia Voigt, applying ideas from economic criticism and functional linguistics, and is fully funded by the Arts and Humanities Research Council UK. Sarah's MPhil thesis focused on representations of hunger in children's literature and received the 2013 Jacqueline Wilson Award.

Sarah Hardstaff

sflh2@cam.ac.uk

1 Cambridge University, Cambridge, UK 
shall explore the ways in which, in children's literature, child characters may knowingly trade upon, or be forced to work around, certain constructions of childhood, as part of and alongside their other forms of labour and economic participation.

The language of children's literature criticism and childhood studies draws heavily on economic concepts such as exchange, transaction and investment; see for example Jacqueline Rose's use of "investment" to describe adults' interest in children and childhood (1992, p. 3), Clémentine Beauvais's emphasis on the adult-child "transaction" (2013, p. 78) or the "growth," "losses" and "gains" of Marah Gubar's writing on kinship and child agency (2016, p. 294). The converse is also true; the language of economics is replete with metaphors we associate with childhood and growing up: infancy, growth, maturity and so on. Indeed, it is verging on cliché to point out the etymological connection in many languages between the words for "offspring" and "interest" (Graeber, 2011, p. 192; Skidelsky and Skidelsky, 2012, p. 79). Despite these textual relations, most research on the economics of children's literature falls under the banner of historical materialism, focusing on the extratextual; for example, the work of Jack Zipes on children's literature and the culture industry (2002a, 2002b), or Susan Honeyman's study of childlore (2010). Jack Zipes' arguments in particular depend on the assumption that exchange under capitalist conditions poses a grave danger to children, while ignoring the possibilities created by children's participation in the economy as producers, consumers and traders. The idea of exchange is no exception, with (entirely legitimate) fears about children being exploited overriding the possibility of the child acting as a canny trader. Furthermore, while the figure of the self-interested agent maximising utility is core to neoliberal discourses of "adultness," the thought of children behaving in this way provokes anxiety.

In this paper I take specific examples from the first of Cynthia Voigt's Tillerman novels, Homecoming (1981), to illustrate the ways in which different notions of childness are conceptualised, used and exchanged between child characters and adults. Homecoming is the first book in Voigt's Tillerman cycle-a series of seven novels published between 1981 and 1989, which follows the story of four children who are abandoned by their parents and are subsequently brought up by their grandmother. Prequels and sidequels form a significant part of the series, with just three of the novels focusing primarily on Dicey Tillerman, the overall protagonist. Dicey is the eldest of the four Tillermans, aged 13 in Homecoming, and in this first novel she leads her siblings on a journey down the east coast of the United States in search of their grandmother. Much of this quest is undertaken on foot without adult supervision.

Unaccompanied children, whether Dickensian urchins or Syrian refugees, and the fictional narratives that spring up around them, tend to generate moral panic of one sort or another. In a recent paper that examines photography of child street labour in the US, Oenone Kubie notes that "Progressive-Era child-savers repeatedly depicted child street labourers as powerless, helpless victims of situations beyond their control ... the rhetoric of reformers diminished the agency of child street labourers" (2016, p. 892). She goes on to point out the historical reality that "children chose how they worked" to an extent (p. 893), and that very often child workers "used to their own advantage the image of the poor, exploited newsboy who just wanted 
to go home" (p. 894). In Homecoming's fictional portrayal of childhood, as with the real-life newsboys, competing notions of childness are produced, consumed and traded as characters negotiate the adult world. As Hollindale writes, "Childhood itself, the first phase of childness, is constantly interacting with empowered adulthood, the second phase of childness, and the chemistry of that interaction at any one time determines the success or failure of adult-child relations" (1997, p. 76).

Dicey and her siblings experience childness- "the quality of being a child" (Hollindale, p. 47) — as something that defines the parameters of their capabilities. At the same time, their awareness of their childness allows them to purposefully exploit adult perceptions of childhood as a fragile state to obtain food, shelter and help. Voigt thus calls into question attitudes about childhood that presume adult competence and child incapacity. To use another economic metaphor, we see how the acts of children are assigned different values compared with those of adults.

\section{Existing Criticism}

Existing criticism of Voigt's Tillerman novels has tended to focus on labour carried out by the characters, whether material or affective. Victor Watson writes about the ways in which the novels depict work, materiality and community as part of his larger work with Margaret Meek which, rather pleasingly, features not one but two economic metaphors in its title: "growth" and "maturity" (2003). Meanwhile, Elizabeth Pearce's doctoral research discusses the ways in which Dicey exercises agency and subversion in her domestic labour (2014), and in the collection Mothers in Children's and Young Adult Literature, Lisa Rowe Fraustino (2016) explores the maternal labour carried out by Dicey and then transferred to her grandmother. My own previous research on Homecoming explores the representation of the "hidden economy," focusing on the tension between agency and determinism as revealed through the children's stealing and scavenging for food (Hardstaff, 2013).

The existing criticism thus highlights the ways in which the Tillerman novels are organised around various types of labour, a trope that already implies certain types of exchange inasmuch as labour is carried out with some expectation or agreement of compensation. In this paper I argue that alongside their physical and emotional work, there is an additional symbolic labour the children must undertake: the labour of performing and embodying childness. I read Homecoming and the exchanges it entails as part of a symbolic economy. I further argue that this symbolic economy underlies both the decisions the children make for themselves with regard to their work and survival, and the ways in which they are treated by others. In their attempts to define this method of reading literature, usually labelled economic criticism, Mark Osteen and Martha Woodmansee write: "Fundamental to this approach is an understanding of texts as systems of exchange involving dynamic patterns of interlocking metaphoric transfer" (1999, p. 36). While Hollindale does not use the term economic criticism, the definition above is more than reminiscent of Signs of Childness. 


\section{Children as Entrepreneurs}

In Homecoming, the transactional nature of childness is emphasised by the main focalising character, Dicey Tillerman. Dicey adopts the same measured and precise mode of thinking when navigating all aspects of the adult world, whether working out where she might be able to buy the cheapest food (e.g. pp. 24, 37) or how best to present herself and her siblings to evade detection or capture. In many ways she appears as an entrepreneur, a self-interested agent acting autonomously to achieve her own goals. As Victor Watson writes:

In Homecoming... movement does not always mean progress but it does always involve meetings with strange people - eccentric, kind, wicked or violent. Dicey's maturation is not simply a matter of observing these people and learning lessons about the USA; she is forced to become the USA capitalist, opportunistic, courageous, worried and sharp witted, a pragmatist defining her family group against the difficulties of survival. (2002, p. 87)

However, Dicey is sometimes forced to recognise that she needs the help of others outside the family to survive, although the ways in which this is achieved often serve to emphasise her resourcefulness rather than her dependence on others. For example, she selects her little brother Sammy to visit an expensive bakery in the hope of making the woman serving "feel sorry for us" (p. 86). This scene is remarkably similar to the episode in Frances Hodgson Burnett's A Little Princess in which Sara Crewe's good manners, humility and kindness leave a lasting impression on the woman running the bakery (1987/1905, pp. 122-124), although Voigt's is a more worldly retelling, lacking Burnett's sentimentalism: Sammy is instructed to appear "brave and pitiful" (p. 87) in order to procure as much bread and pastry as possible for fifty-one cents. His success in this transaction depends on his ability to knowingly induce pity in this way, as well as on his physical appearance as a young child, drawing on both performative and material signs of childness. The classic motif of the loaf of bread stolen for or gifted to the hungry child can be found in an array of texts: Les Misérables, Jane Eyre, The Hunger Games and so on. Yet Sammy's efforts reverse the implied direction of exchange: rather than an act of charity, the bakery scene is reimagined as an act of entrepreneurialism. The allusive richness of this scene would likely go unrecognised by the characters taking part, who do not themselves mention any bread-related stories other than Hansel and Gretel (p. 4). We see here instead multiple layers of exchange, from the financial transaction between Sammy and the shopkeeper, their symbolic trading of bravery for pity, and the communication of extratextual references between the author and the reader.

Lucy Pearson, in response to the original paper on which this article is based, queried whether categories such as "entrepreneurial" or "helpless" could really be considered forms of childness rather than merely forms of humanness. For example, just as the children must accept help and admit dependence on others, so too must the novels' adults. This feature of Voigt's work recalls Gubar's warnings against pigeonholing children; she writes: "Our capacities for reflectiveness, 
rationality, self-control-or whatever qualities we deem necessary before agents should be allowed to make their own choices free from parental (or in loco parentis) supervision ... do not always and inevitably correlate with age" (2016, p. 294). Similarly Hollindale argues that "we should give due weight both to the differences between child and adult and to the similarities and continuities that link us all" (1997, p. 44). Pearson's argument here centres not so much on continuities as on an equivalence between power relations such as child/adult and citizen/state. Thus when the children's grandmother Abigail Tillerman has to be persuaded to claim welfare, she is in a similar position to the children in seeking to access help from further "up" the hierarchy. Abigail tells Dicey towards the end of Homecoming:

"You've worn me out. You can stay, you can live with me .... You'll live with me and we'll see lawyers about adoption and take government money and we'll plant Christmas trees and raise chickens, whatever we have to do, whatever ideas James cooks up that we can't talk him out of." (p. 387)

Yet as with the bakery incident, this is reconfigured as maximising utility rather than receiving charity, and it is Abigail's grandchildren who encourage and persuade her to adopt this perspective. Partaking of welfare never sits easily with Abigail's adult concept of independence (see Dicey's Song, 1982, p. 194), but for the children it represents a non-negotiable survival tactic.

Despite playing on others' notions of childhood innocence, Dicey secretly regrets Sammy's induction into a shadow economy: when he begins to steal, she is faced with a moral dilemma, believing that if the children are forced to steal, "then it should be Dicey herself to do it. Not a little boy six years old" (p. 71). Nevertheless, the feral, criminal childness so feared by adults in the novel is here recharacterised as "smart" and "brave." The Tillermans also exploit other young people, drawing on notions of freedom and adventure to obtain transport from two boys who have access to a boat; specifically, they create a narrative about their parents' ineptitude based on a knowing solidarity amongst children- "you know how parents are" (p. 233), while simultaneously flattering the boys' sense of ownership and control of the boat. The children are delighted that "we made them do what we wanted them to do" (p. 235). In certain tourist areas, the children are rendered invisible, again able to hide their abandonment by exploiting the idea of the adventuring child and using their age as "natural camouflage" (p. 254), again drawing on both the performative and material signs of childness.

As well as trading on ideas of the child as a hungry innocent or a spirited adventurer, the Tillermans must work to prove that children can be useful, resisting their cousin Eunice and grandmother Abigail's ideas about children being expensive and too much bother. Dicey explains to her siblings:

We have to get started on something useful before she wakes up. That way, she'll keep us here today .... We pretend we're not even thinking about staying here. But every day we do something that needs to be done so it's worth her while to keep us. (p. 331) 
We can't ask, we just have to do things. We can't give her a chance to say no, because if we do then that's what she'll say. And we've got to get back to work. (p. 336)

In Dicey's Song (1982), the sequel to Homecoming, Dicey convinces a local shopkeeper to give her a job, and consciously presents the image of the entrepreneurial child: useful, quick and cheap. She asks for a dollar an hour as a wage: "She was under age, so she couldn't charge much" (p. 11). Despite their entrepreneurial ability to trade on different ideas of childness, the Tillermans also find their activities limited by legal restrictions that exist for the protection of children.

\section{Children as Illegal}

Throughout their journey Dicey is constantly afraid of being detected by authorities - the police, social services, and so on. The boundary between legitimate and illegitimate, legal and illegal behaviour for children is fuzzy, as we can see in the following passage: "Fear of being caught woke Dicey before dawn. It was one thing to be seen camping in the woods; that might be kids having a night out with their parents' permission. But four kids sleeping in an unfinished house - that would be police business" (1981, p. 38).

The speculative thinking and modality of this passage-_might be", "would be"-shows how Dicey's actions are contingent upon adult ideas about what children should be doing. Indeed, the limits of the Tillermans' movements and actions are determined by their status as children, which prevents them from labouring in the formal economy and positions them legally as needing adult protection, irrespective of their own feelings and choices. This is despite the fact that the costs of moving through the world as a child are no lower for the Tillermans than for adults, as symbolised from the start of the novel when we learn there is no child rate for the bus tickets the children need to get to their aunt's hometown (p. 15).

Homecoming presents a child's right to survival as a central premise. Yet in Dicey's society, the opportunity to undertake legitimate forms of work is denied, largely due to a dominant discourse of childhood that is also identified by Hollindale. He writes:

In western societies as a whole today, there would be general agreement that childhood is a period of economic dependency ... last[ing] well into the teens, and during this period it is right to place strict legal limits on the kinds of work, and amount of work, that children can do for money. (p. 77)

Thus in the world depicted by Voigt, children are not allowed to work to earn money in the same way as adults due to legal restraints that exist for their own protection. These restraints work against Dicey and her siblings as they presuppose that adults are capable of adequately providing for children. Dicey and her family engage in illegal poaching and scavenging as means of survival, and also use their labour to access money, food and protection at the level of the informal economy-carrying out unpaid work for their cousin Eunice, a travelling circus, and their grandmother 
Abigail, and through casual work for shopkeepers and Rudyard, a farmer who attempts to kidnap the children. Obtaining and carrying out casual work is often presented as a fun and fulfilling activity for Dicey: we discover that "by bargaining this way, before she knew it, Dicey had six regular jobs, washing the city grime off the windows of neighborhood stores" (p. 176). Illegal work, forbidden by her adult cousin, is reconfigured as a kind of freedom, as it is for the newsboys: Dicey becomes a "go-getter" (p. 186). This freedom comes under question later, when an abusive employer claims he has legal papers showing his guardianship of the Tillermans, and clearly expects his word to be believed over that of the children.

In his discussion of Seventeen Against the Dealer (1989), the final novel in the Tillerman series, Watson questions Dicey's entrepreneurial self-concept. He argues instead that Dicey "buys into the central capitalist deception in which free choice and compulsion are inseparably confused .... She gives her assent to the circularity of this economic treadmill because she is convinced that she is tougher than the system" (2003, p. 114). Watson thus argues that children cannot act as free agents (but crucially, in his analysis, neither can adults). At regular intervals in Voigt's narrative, we find moments of pause and panic that certainly seem to reflect compulsion over choice:

There was nothing for it though, was there? Just going ahead. People might give them food. She might be able to earn food or money, somehow. She couldn't think how they'd manage it. But they would have to manage it, somehow. Then she didn't think any more about it. She couldn't. (1981, p. 30)

The explosion of modal verbs in this passage is typical of Dicey's reflections in her darkest moments: childness unbound from the institutional constraints of family, home and school is contingent upon all kinds of unknown variables. This "free market" childness, if you will, grants no real choices and bears no guarantees of survival.

The children's acts of working and fending for themselves are seen not just as illegal for their own protection, but also linked to other forms of illegality: childness is imagined as a feral, criminal state by some adults in the book. In his remarks on the twentieth anniversary of Signs of Childness, Hollindale (2017) castigated our cultural response to children's criminal capacity: we consider crimes of equivalent horror to be worse when committed by children rather than adults, whereas the opposite should be the case. While the Tillermans are only implicated in petty, nonviolent crimes, this harmful attitude to child criminality is still in evidence. Early in Homecoming, as the children come to realise that they have been abandoned, a security guard accuses Dicey of breaking windows at the mall. His assumption is that youths are responsible, and he seems to relish the power he holds over potential perpetrators. "You haven't got a chance," he shouts at Dicey, despite the fact that she outpaces him both intellectually and physically (p. 17). This statement reveals a paradox of agency: the guard assumes the vandals are children, thus considers children as capable of criminal activity, but simultaneously also positions children as helpless against both the physicality and social power of adults.

This guard is the first of many adults who wish to control or capture the Tillermans. Adults in Dicey's world feel entitled to dictate the movements of children, but 
also harbour fears of childness - that is, of self-aware and self-reflective childhood untamed by adult norms. The children are chased away from shelter (p. 27), "stared at ... suspiciously" in shops (p. 86) and so on. Multiple police officers, at least one armed, come to search the park where the children have been staying after Sammy temporarily steals a wallet (pp. 81-82). Suspicion is also the default response to childness from the bus driver who takes them to Delaware (p. 210), and even from performers at the circus, who are themselves active participants in a shadow economy (p. 257). Cousin Eunice also conceptualises childness as a dangerous and alien force. She perceives the Tillermans as physically alarming, despite their age: "to see four children on my doorstep ... I was afraid. You hear of such strange things happening these days. Especially to women who live alone" (pp. 139-140).

Yet Voigt combats these attitudes by emphasising the strong moral compass of the children, imbuing them with an innate goodness which, as with countless characters from Cinderella to Harry Potter, seems at odds with a childhood forged by a neglectful upbringing and their current dire circumstances. For instance, when the children tie up a dinghy they have "borrowed" to cross a river, we are told: "Dicey thought that if she left the dinghy there it had a good chance of being claimed or returned" (p. 99), and later, “[b]ecause Dicey didn't feel right about going into the refrigerator or the pantry, they ate tomatoes and cucumbers from the garden" (p. 335). The concept of childhood sold to the reader by the narrator ultimately falls back on Victorian models of the deserving poor, despite the more perceptive rewriting of stock scenes such as that in the bakery. The main exception to this occurs when the children reach a point of extreme despair - then Dicey refers to the money in the wallet as having been "found" by Sammy, rather than stolen (p. 108). Shortly after this, as if in haste to immediately redeem the children, we learn that after eating, "Dicey remembered her manners. It was easier to remember manners with milk in her stomach and food on the way" (p. 113). The hungry child is absolved of her feral behaviour, but once her stomach is full she must conform to more socially acceptable modes of childhood. Dicey's childness therefore involves constant negotiation between her and her siblings' bodily and emotional needs on the one hand, and on the other, the social conventions and restrictions that would see them go hungry and lose agency.

\section{Children as Helpless}

While the Tillermans discuss and decide their actions based on complex, collaborative moral frameworks, on their journey they often encounter the idea that children are helpless, innately unable to act in their own best interests. Generally, children are often not considered to have legal capacity over many areas of their life. This legal notion of "capacity" pertains to people's ability to make independent decisions in their own best interest, to act as a rational agent in other words, with "incapacity" defined as a "lack of full legal competence in any respect" (Law et al., 2014, n.p.). The belief that children cannot act in their own best interests but adults can is what makes it possible to hold the view that a laissez-faire state enables happy individuals, creative enterprise and a just economy, while simultaneously holding that 
laissez-faire parenting produces unhappy, wild and spoilt children. We have talked about this perceived incapacity in terms of children as employees and criminals, but a competing idea of childness can be found in commentary on the children's helplessness, vulnerability and inability to make good decisions. This is a position that is interrogated by Dicey and in Voigt's narrative comments. As we have already seen, Dicey's focalised narration makes extensive use of the modal language of "can", "can't" and "could"/"couldn't" throughout the novel—sometimes dealing with permissions, but far more often to do with capacity, as when she says, "sometimes ... I feel as if we could do just about anything. Because we're the Tillermans" (p. 43). Despite the hedging words-“sometimes", "just about"- there is a clear sense here of the children's collective agency, spurred on by Dicey's belief in them.

Moreover, the children are depicted as quite capable of understanding their legal status, discussing their rights, the notion of being "owned" by parents, who control children's bodies, finances, healthcare, and so on (p. 74). In the same scene it is pointed out by the narrator, and focalised through Dicey, that "the whole world was arranged for people who had money-for adults who had money. The whole world was arranged against kids. Well, she could handle it. Somehow" (p. 74). Children's presumed lack of capacity is exacerbated by a socioeconomic system that further disempowers them.

However, the older Tillerman children are not convinced of the capacity of the younger two: Dicey and James, in their awareness of their own childness and from a position of relative maturity, are starting to think about what it means to be a child and what a child can do. Discussing Sammy, the narrator tells us that "you couldn't go off and leave a six-year-old, alone, in the woods" (p. 20), the suggestive use of second person reinforcing a concept of childness as helplessness. Little sister Maybeth is strongly associated with childhood innocence and an almost Dickensian goodness and passivity (see Hollindale, 1997, p. 100), but she does not have the confidence or ability to perform this mode of childness to the advantage of her family; this is discussed explicitly when the children are trying to decide which of them should enter the bakery and play at being pitiful to gain extra food for their money. The perceived incapacity of the children becomes a source of speculation, primarily by those who wish to exploit them, such as Rudyard, a farmer who offers the children temporary employment, but also by Abigail, who refuses to accept that Maybeth can do anything. She does not initially address Maybeth directly or consider her capable of assessing her own abilities. The children also trade on the beliefs of others in their incapacity and lack of knowledge, as for example when Sammy tells the baker that he cannot remember his parents' phone number to avoid further questioning (p. 88).

There are also occasions when Dicey draws on the collective capacity and responsibility of all the children: "We're gonna have to think up some ways of getting money" (p. 35). Collective language is used in the narration as well as in the dialogue; for example, "They knew better" (p. 38). This serves to counter the characterisation of the children as helpless by adults, and indeed, the children's capabilities are stretched by Voigt to the absolute limit of plausibility. In another example of author-reader interaction, the more recent young adult novel Eleanor \& Park (Rowell, 2012) draws our attention to the way in which Voigt's 
construction of childness is idealised, only possible in fiction. After Eleanor runs away, leaving her younger siblings behind, she reflects:

If Eleanor were the hero of some book, like The Boxcar Children or something, she'd try. If she were Dicey Tillerman, she'd find a way. She'd be brave and noble, and she'd find a way. But she wasn't. Eleanor wasn't any of those things. She was just trying to get through the night. (Rowell, 2012, pp. 296-297)

The Tillerman children are highly skilled: they work together to collect firewood, fish for clams, wash their clothes, can all swim safely in the ocean, are "accustomed to boats" (Voigt, 1981, p. 98) and so forth. Six-year-old Sammy asserts his capabilities, in response to Dicey's imperative not to talk to anyone about their circumstances: "I wouldn't do that. I'm not stupid" (p. 69). Perhaps such assertions can be read as indicative of a child's confidence, a confidence that is "childly" and can be valued despite its limitations, as opposed to the derogatory "childish" or the mawkish "childlike" (Hollindale, 1997, p. 45). By contrast, Dicey admits or reflects on how little she knows and this is a key part of her maturation process; she also questions herself and positions herself on a spectrum from certainty that she can to certainty that she can't.

Dicey's own capabilities are attributed to her mother's incapacity to care for the children, as seen when she recalls being responsible for her siblings from the age of eight (Voigt, 1981, p. 32). Yet surrogate motherhood is not perceived as a suitable responsibility for a child in the same way as casual entrepreneurialism, and is firmly rejected by Voigt both in this novel and in Dicey's Song as "unchildly." Motherness also constrains: "She wanted to fight .... Or to run .... But she had the two little ones holding on to her" (p. 194). Pearce argues that "as the eldest, Dicey automatically assumes responsibility for her siblings, even as she dreams of finding someone else to accept this labor; she accepts that she is now responsible for the woman's work her mother has abandoned" (2014, p. 139). Similarly, Fraustino talks about the binds of motherhood in the Tillerman novels and the way this burden is passed on to the grandmother, while their absent father Francis gets away without having any responsibilities: "When faced with an unfit and unwed mother, the backlash culture's next best choice is the mother's mother .... Fathers are allowed not to want children, often even allowed to leave without being demonized by it, in children's literature as in other areas of popular culture" (Fraustino, 2016, p. 221).

While it is beyond the scope of this article to explore ideas of mothering and motherhood in the Tillerman series in detail, I would query whether being responsibility-free is in fact the same thing as being free. Nonetheless, in Dicey's Song, Dicey struggles to come to terms with her own child status, and must learn to let go of adult responsibilities. This process begins towards the end of Homecoming when Abigail starts to treat Dicey as a child while still respecting her enough to speak frankly and share information. Overall, once the children are taken under permanent adult protection, both their fraught illegal status and their entrepreneurial go-getter status are to some extent neutralised. 


\section{Children as Gendered}

Closely connected to ideas about helplessness, another aspect of childness traded in the novels relates to the gendering of children. When Rudyard looks at Maybeth, he sees her prettiness and archetypal feminine passivity through the eyes of a predator (Voigt, 1981, p. 267). Similarly, Cousin Eunice sees Maybeth with a fixed view, and dresses her up to show off to her friends, drawing on a concept of childness that is bound up with "girlness," turning Maybeth into a doll, or in other words, a commodity: "Silent and peaceful [like a dead child], she went off to church with Cousin Eunice on Sundays dressed in a frilly pink dress Cousin Eunice had bought her, wearing a little straw hat with flowers on the brim and white gloves. She even had a little white purse" (p. 168). The purse in particular, the contents of which remain unknown, is a gift which acts as a symbolic affront to the Tillermans' struggles with money. Eunice allows the children to participate in the economy only as a game of dress-up or when confined to the domestic space. Other gifts the children receive also fix them in set gender roles: in a bundle of charity clothes they are given, "[f]or Dicey and Maybeth there were dresses, for the boys shirts and trousers. Dicey didn't like dresses" (p. 156).

On the other hand, Dicey is often able to turn her ambiguous gender presentation to her advantage. For instance, at the beginning of the novel she makes the most of the mall security guard mistaking her for a boy. He tells her to go home, saying "if you were a girl, I'd walk you over" (p. 13). Dicey recognises the dangers of other people's gendered concepts of childhood; in this case, a certain type of intrusive over-protectiveness of girls on the part of the guard. Throughout Homecoming, she is frequently mistaken for a boy, often leading those she encounters to inflate their ideas of her capabilities and independence. These conflicting images of childhood afford different privileges, which Dicey in particular is able to recognise and exploit: Maybeth is valued for her gender-conforming appearance and behaviour, albeit this is a form of valuation that objectifies her, while Dicey can draw on male privilege, at least on a superficial level, to access additional opportunities for agency. Dicey also states: "It's safer to be a boy than a girl .... People leave boys alone more" (p. 57). The boy/girl binary entails the same kinds of concern about capacity and the need for others to intervene as the adult/child one.

\section{Conclusion}

In the Tillerman novels, Voigt constructs an overarching sense of childness whereby children may be knowing and experienced, but are still in need of a safe home, and not just any home, but one in which their individual needs, wants and attributes are respected. This idea travels well throughout a novel, but is sadly lacking in the film version of Homecoming (1996), where our gaze is turned on the visible childishness of the characters, emphasising their physical vulnerability while ignoring their mental agency. Interestingly, Dicey is presented as far less gender-neutral than in the novel. 
Turning away from children's literature, there is a wider theoretical point at stake here too. Throughout this article I have tried to talk about childness as a form of currency, in the sense that it acts as both a means of exchange and a store of value. This symbolic economy of childness also provides a conceptual base from which we can question some of the assumptions of traditional economic thought. As a concept, childness allows us to explore exchanges that presuppose varying degrees of dependence on others, bringing into question the assumption that our default setting is as autonomous self-interested agents, an assumption which I would argue is perhaps the defining fiction of adultness.

Open Access This article is distributed under the terms of the Creative Commons Attribution 4.0 International License (http://creativecommons.org/licenses/by/4.0/), which permits unrestricted use, distribution, and reproduction in any medium, provided you give appropriate credit to the original author(s) and the source, provide a link to the Creative Commons license, and indicate if changes were made.

\section{References}

Beauvais, Clémentine. (2013). The Problem of "Power": Metacritical Implications of Aetonormativity for Children's Literature Research. Children's Literature in Education, 44(1), 74-86.

Burnett, Frances Hodgson. (1987/1905). A Little Princess. New York: Bantam.

Fraustino, Lisa Rowe. (2016). Abandoning Mothers. In Lisa Rowe Fraustino and Karen Coats (Eds.), Mothers in Children's and Young Adult Literature: From the Eighteenth Century to Postfeminism (pp. 216-232). Jackson, MS: University Press of Mississippi.

Graeber, David. (2011). Debt: The First 5000 Years. New York: Melville.

Gubar, Marah. (2016). The Hermeneutics of Recuperation: What a Kinship-Model Approach to Children's Agency Could Do for Children's Literature and Childhood Studies. Jeunesse: Young People, Texts, Cultures, 8(1), 291-310.

Hardstaff, Sarah. (2013). Poachers and Scavengers: The Hidden Economy in Modern Children's Fiction. Unpublished MPhil Thesis. University of Cambridge.

Hollindale, Peter. (1997). Signs of Childness in Children's Books. Stroud: Thimble Press.

Hollindale, Peter. (2017). Peter Hollindale on Signs of Childness in Children's Books. Presented at Any Signs of Childness? Peter Hollindale's Signs of Childness in Children's Books (1997), 20 years on. University of York, 5 May 2017.

Honeyman, Susan. (2010). Consuming Agency in Fairy Tales, Childlore, and Folkliterature. New York \& Abingdon: Routledge.

Jean, Mark. (1996). Homecoming. Los Angeles, CA: Hallmark Entertainment.

Kubie, Oenone. (2016). Reading Lewis Hine's Photography of Child Street Labour. Journal of American Studies, 50(4), 873-897.

Law, Jonathan and Martin, Elizabeth A. (2014). A Dictionary of Law. 7th ed. Oxford: Oxford University Press. Accessed October 2017 from http://www.oxfordreference.com/view/10.1093/acref/97801 99551248.001.0001/acref-9780199551248-e-1896?rskey=KAMWW3\&result=2017.

Osteen, Mark, and Woodmansee, Martha. (1999). Taking Account of the New Economic Criticism: an Historical Introduction. In Mark OSteen and Martha Woodmansee (Eds.), The New Economic Criticism (pp. 3-50). London: Routledge.

Pearce, Elizabeth Ann. (2014). Limitation, Subversion, and Agency: Gendered Spaces in the Works of Margaret Mahy, Cynthia Voigt, and Diana Wynne Jones. Unpublished PhD dissertation. Illinois State University.

Rose, Jacqueline. (1992). The Case of Peter Pan, or The Impossibility of Children's Fiction. Philadelphia, PA: University of Pennsylvania Press.

Rowell, Rainbow. (2012). Eleanor \& Park. London: Orion.

Skidelsky, Robert, and Skidelsky, Edward. (2012). How Much is Enough? Money and the Good Life. London: Penguin. 
Voigt, Cynthia. (1981). Homecoming. New York: Atheneum.

Voigt, Cynthia. (1982). Dicey's Song. New York: Atheneum.

Voigt, Cynthia. (1989). Seventeen Against the Dealer. New York: Atheneum.

Watson, Victor. (2003). Cynthia Voigt. In Margaret Meek and Victor Watson (Eds.), Coming of Age in Children's Literature: Growth and Maturity in the Work of Philippa Pearce, Cynthia Voigt and Jan Mark (pp. 85-124). London: Continuum.

Zipes, Jack. (2002a). Breaking the Magic Spell: Radical Theories of Folk and Fairy Tales. Lexington, KY: University Press of Kentucky.

Zipes, Jack. (2002b). Sticks and Stones: The Troublesome Success of Children's Literature from Slovenly Peter to Harry Potter. New York: Routledge. 